\title{
Reimund Kvideland uskus, et folkloor ei sure kunagi
}

\section{6. juunil 2006 suri 71-aastasena norra folklorist Reimund Kvideland.}

R. Kvideland (1935-2006) õppis Oslo, Maini-äärse Frankfurdi ja Kopenhaageni ülikoolis põhjamaade filoloogiat, ajalugu, kirjandust ja rahvaluulet ning alustas oma folkloristikarjääri 1966. aastal Bergeni Ülikooli äsjaloodud folkloristika õppetooli lektorina, kus temast kujunes kiiresti üks eriala uuendajaid. Ta suutis tõestada selle teadusdistsipliini vajalikkust nii kaasaegsete protsesside kui ka traditsiooni uurimise seisukohalt.

R. Kvideland oli nii tunnustatud teadlane kui ka suurepärane administraator. Ta oli 1963. aastal asutatud erialatudengeid ja noorteadlasi ühendava Põhjamaade Etnoloogide ja Folkloristide Töörühma (Nordisk Etnolo-

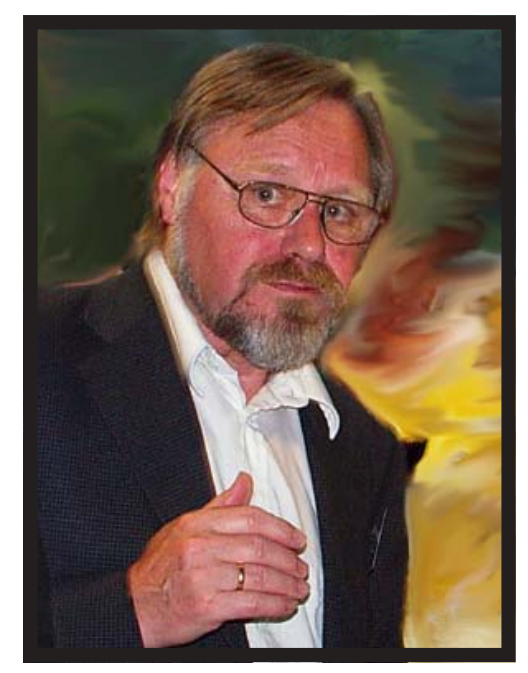

Norra folklorist Reimund Kvideland (1935-2006). gisk Folkloristisk Arbejdsgruppe = NEFA) esimene esimees. 1971. asutas ta folkloristikaajakirja Tradisjon, millest kujunes peagi skandinaavia folkloristide olulisim väljaanne, ning oli 25 aastat selle peatoimetaja. Aastatel 1987-1990 oli ta Rahvusvahelise Etnoloogia ja Folkloori Ühingu (Société Internationale d'Ethnologie et de Folklore) ja 1989-1995 Rahvusvahelise Rahvajutu-uurijate Seltsi (International Society for Folk Narrative Research) president. Aastatel 1991-1997 töötas ta Soomes Turus Põhjamaade Folkloori Instituudi (Nordic Institute of Folklore = NIF) direktorina. 1998. aastal valiti ta Bergeni Ülikooli professoriks. Hulk aastaid oli ta Internationale Volkskundliche Bibliographie ja Nordische Bibliographie für Eth- 
nologie und Folkloristik ning paljude Eurooopa ja Aasia teadusväljaannete kaastööline.

Reimund Kvidelandi teaduslike huvide ja publikatsioonide temaatiline haare oli lai. Ta käsitles nii narratiive kui ka laule. Laulu-uurimise valdkonnas tegi ta endale nime emigrantide laulude ja raudteetööliste ballaadide uurijana. Narratiiviuurijana on ta käsitlenud imemuinasjutte, muistendeid ja memoraate, analüüsides nii nende funktsionaalseid aspekte kui ka žanrilisi erijooni ning vaadeldes repertuaari- ja levikuprobleeme. Ta jõudis tegelda ka rahvaluuleteaduse ajalooga, toimetada rahvajutukogumikke ja teatmeteoseid ning teha kaastööd muinasjutuentsüklopeediale (Enzyklopädie des Märchens).

\section{Intervjuu Reimund Kvidelandiga Tartus Rahvusvahelise Rahvajutu-uurijate Seltsi 14. maailmakongressi ajal 27. juunil 2005}

Ave Tupits

Teie kodumaa on Norra. Kas te võiksite rääkida veidi oma taustast ja sellest, kuidas jõudsite folkloorini?

Kui alustasin Oslos ülikooliõpinguid, kohtasin üht oma kodukandist pärit tudengit, kes ütles, et sellest aastast hakatakse esmakordselt õpetama folkloristikat. Nii läkski, et ma ei hakanud õppima ajalugu, nagu olin kavatsenud, vaid folkloristikat. Lisaks õppisin ka ajalugu ning norra ehk põhjamaade keeli ja kirjandust. Aga just rahvaluule oli see, mis mu meeli köitis. Lõpuks küsisin õppejõult, kas ma ei saaks õppida folkloristikat peaainena. Ta ütles: jah, saad küll, sest sa saad töötada ülikooli raamatukogus (olin vahepeal omandanud raamatukoguhoidja kutse). Ja lisas: sulle jääb võimalus töötada ka kooliõpetajana, kuid sa ei saa kunagi töökohta, mis oleks seotud rahvaluulega, sest selliseid töökohti lihtsalt pole.

Kui olin aga lõpetamas magistriõpinguid, tuli ta ruumi, kus kirjutasin magistritööd, ja ütles: "Kiirusta! Saadaval on kaks uut töökohta ja üks neist sobib just sulle! Üks töökoht tuleb Oslosse, teine läänerannikule Bergenisse. Et sina oled kõige noorem, saadame su Bergenisse."

Alustasin seal tööd ainsa folkloristina, ehitades üles õppetooli ehk osakonna. See oli minu saatus, kui nii võib öelda. Jäingi Bergenisse ja olin sealt ära 
vaid 7-8 aastat, mil töötasin Turus Põhjamaade Folkloori Instituudi direktorina.

Õige varakult mõistsin, et folkloristika on rahvusvaheline teadusharu. Hakkasin osalema rahvusvaheliste organisatsioonide töös. Juba 1964. või 1965. aastal $^{1}$ osalesin Rahvusvahelise Rahvajutu-uurijate Seltsi (ISFNR) maailmakongressil Ateenas. See oli huvitav kogemus. Sain suhelda vanade, tunnustatud teadlastega paljudest maadest. Nii see algas.

\section{Mis on olnud teie peamised huvivaldkonnad folkloristikas? Olete uuri- nud mitmesuguseid rahvajutte?}

Mul ei ole olnud võimalik uurida ainult üht valdkonda, seda eelkõige õpetamiskohustuse tõttu. Ühel semestril on tulnud õpetada rahvalaulu, teisel mõistatusi ja rahvajutte jne - ma olin ju ihuüksi, ainuke rahvaluuleõppejõud.

Peagi sattusin vaimustusse avastusest, et folkloor ei ole midagi ajalukku vajunut, midagi väljasurnut, nagu oli õpetatud ülikoolis. Juba 1960. aastate keskpaigas alustasin üsna suure lastefolkloori, eriti laste jutustamise projektiga - see hõlmas kümme tuhat koolilastelt kogutud juttu ja anekdooti. Minu arvates oli see ka väga hea õppematerjal, mis võimaldas õpetada tudengitele, et rahvaluule on midagi elavat, osa kultuurist, meie argikultuur. Nii ma keskendusingi mõneks aastaks lastepärimusele.

Aga olen uurinud ka rahvalaulu. Minu suhtumist rahvalaudesse on oluliselt mõjutanud Ina-Maria Greveruse ${ }^{2}$ raamat Der territoriale Mensch. I.-M. Greverus läheneb rahvalaulule antropoloogilis-kirjanduslikult. Hiljem Saksamaal Neussis viibides jõudsin - võib-olla mõjustatuna Ernst Klusenist $^{3}$ - järeldusele, et laulmine on üks olulisi inimtegevusi. Peaksime üritama analüüsida mitte ainult laulutekste, vaid ka laulmist ennast kui kultuuriprotsessi.

Minu põhiliseks huviobjektiks on olnud aga rahvalikud narratiivid, rahvajutud. Esimese sellealase uurimuse kirjutasin arhiivimaterjalide põhjal - rahvajuttude jutustajatest. See on muidugi üks võimalus - näha või uurida rahvajuttude sotsiaalset konteksti, sotsiaalset funktsiooni arhiivimaterjali alusel. Usun, et välitöid on võimalik teha ka arhiivides.

\section{Kuidas nii?}

Tuleb lugeda arhiivimaterjali antropoloogi pilguga, mitte pelgalt tekstina. Sellist meetodit kasutades näeme folkloori funktsioone. Ent teisalt peaksime uurima elavat jutustamist. Leian, et jutustamisel on tänapäeva ühiskonnas, meie kultuuris väga olulise osa. Võimalik, et me ei ole varasematel ajajärkudel 
kunagi nii palju jutustanud kui praegu. Ülikooliõpingute ajal ei näinud ega teadnud me seda. Olime selles suhtes pimedad ning mõtlesime eelkõige muinasjuttudest ja usundilistest muistenditest. Aga kui jälgime tänapäeval inimesi nende argitoimetustes, siis räägivad nad kogu aeg midagi. Just seepärast hakkasid mind paeluma anekdoodid. Arvan, et igaüks meist oskab rääkida mõne anekdoodi, mõned aga suudavad rääkida sadu. Tänapäeval on peaaegu võimatu dokumenteerida anekdoodipärimust selle kogumahus, sest see on nii mitmekülgne ja ulatuslik. Seda leidub nii trükistes kui ka suulises kommunikatsioonis ja nüüd ka internetis.

Mida ütleksite folkloori ja folkloristika olukorra kohta nii Norras kui maailmas üldse? Kas te julgete ennustada, milliseks kujuneb folkloristide tulevik?

Julgen öelda, et folkloor ei sure kunagi välja, aga see muutub. Mõned žanrid hääbuvad, samas kujuneb uusi. Seega olen väga optimistlik selles suhtes, mis puudutab rahvaluulet ennast. Aga kas ka folkloristikal, st rahvaluule uurimisel on tulevikku, see on juba kahtlasem. Raske on öelda, kuidas see areng kulgeb. Kui vaatame ajalukku, 19. sajandi folklooriuurimisse, näeme, et rahvaluule oli rahvuslik jõud, see oli ka poliitiline jõud. Folkloor oli paljudes maades

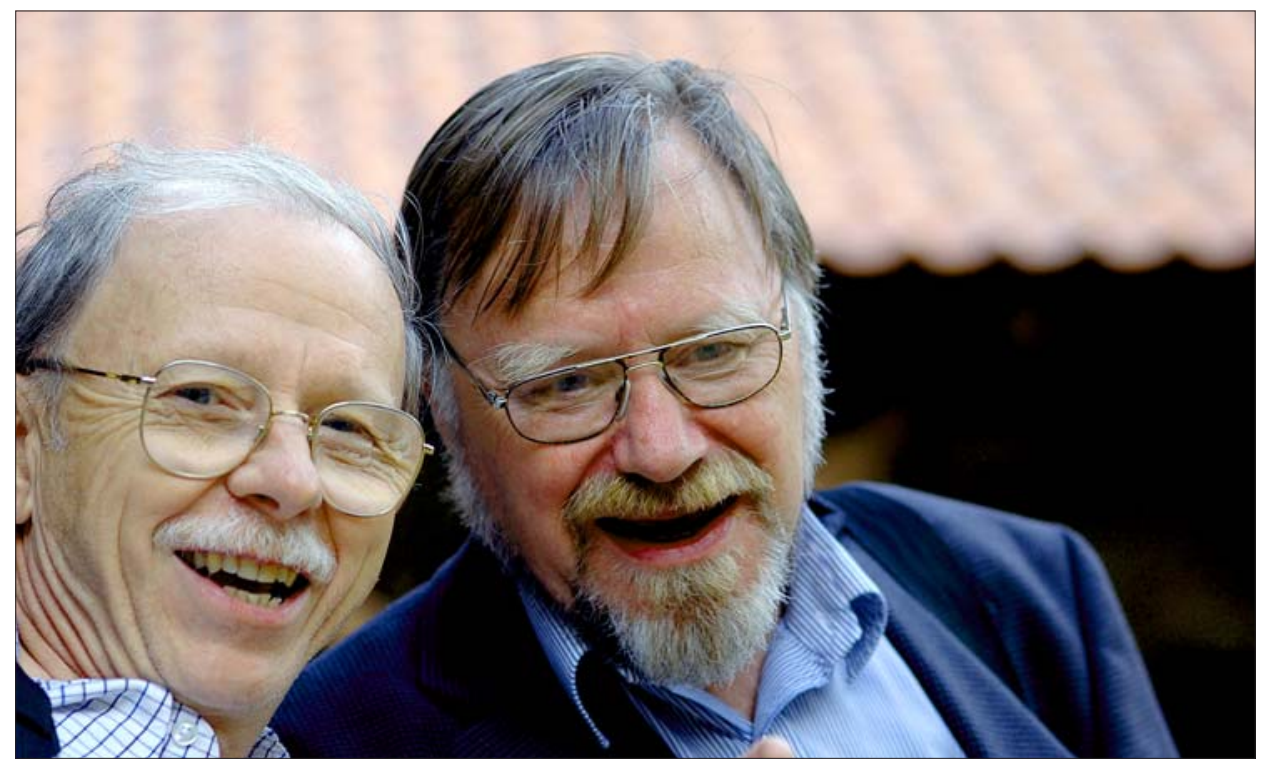

2005. aasta suvel Tartus peetud Rahvusvahelise Rahvajutu-uurijate Seltsi 14. maailmakongressilt jäi Reimund Kvideland (paremal) meelde seltskondliku ja rõómsameelsena, nagu ka tema kolleeg Vermonti Ülikoolist Wolfgang Mieder. Alar Madissoni foto. 
vahend rahvusliku eneseteadvuse ülesehitamiseks. Nii oli see Norras, Soomes ja Eestis, kui nimetame ainult mõningaid. Ka Saksamaal, sest Saksamaa oli killustunud paljudeks pisiriikideks. Samas sellistes maades nagu Prantsusmaa ja Inglismaa folklooril niisugust funktsiooni polnud, see polnud nii vajalik, sest need olid tugevad rahvusriigid.

Tänapäeval - vähemalt Norras - ei ole poliitikud folklooriuurimisest enam huvitatud. Seetõttu ma folkloristika tuleviku osas nii optimistlik ei ole. Asi näib liikuvat selles suunas, et folkloristikat mõistetakse pigem kui kultuuriuuringuid. Mul on tunne, et tänapäeva tudengid ei mõista tegelikult rahvaluuležanre, rahvaluulet kui sellist. Ja kui see arusaam puudub, on minu arvates võimatu folkloori uurida. Muidugi on raske ennustada, mis saab tulevikus.

Olete olnud Rahvusvahelise Rahvajutu-uurijate Seltsi president. Millised mälestused on teil sellest ajast?

Minule on rahvajutu-uurijate maailmakongressid olnud alati tohutuks inspiratsiooniallikaks edasises töös. Suurfoorumil on võimalik saada osa väga laiast teemade ja valdkondade spektrist. Olen saanud palju uusi ideid, uusi teemasid, uut folkloorset uurimismaterjali. Me kõik saame uusi ideid. Ka informaalsetest aruteludest ettekannete vaheaegadel ja õhtuti - need on sama olulised kui ettekanded ise.

ISFNRi presidendikse olemine oli ülimalt huvitav aeg. Õppisin palju. Mul oli sel viisil hea võimalus tutvuda väga paljude folkloristidega kogu maailmast. See andis võimaluse reisida ja kohtuda teadlastega, keda ma ilma ISFNRi töös kaasa löömata ei oleks kohanud. Leian, et just tänapäeval vajame sellist foorumit nagu ISFNR, osalt seetõttu - nagu ütles Galit Hasan-Rokem ${ }^{4}$ Tartukongressi avaõhtul -, et meil on küll väga palju metodoloogilisi ja teoreetilisi võimalusi, kuid pole ühtegi domineerivat koolkonda. Sellepärast ongi oluline, et kohtuksime ja arutaksime kõiki võimalusi, oleksime avatud uutele lähenemistele. See on ehk niisuguse foorumi olulisimaid ülesandeid, et see annab meile võimaluse õppida ja avastada uusi lähenemisi või vähemalt vanade lähenemiste moderniseeritud vorme.

\section{Mida soovite öelda eestlastele?}

Loodan, et see kongress on Eesti folkloristikale abiks. See on sellist laadi abi, mis aitab folklooriuurimisel edasi minna. Loodan, et saate uusi ideid, mida tulevikus edasi arendada. Eestis on suurepärased võimalused: on võrratu arhiiv ja võimalus jätkuvalt teha välitöid, olete välitöö ja arhiivitöö eksperdid ning tugevad uurimistöös. Selles suhtes olen vägagi optimistlik. 


\section{Kommentaarid}

${ }^{1}$ Rahvusvahelise Rahvajutu-uurijate Seltsi 4. maailmakongress peeti Ateenas 1.-6. septembrini 1964 (toim).

${ }^{2}$ Ina-Maria Greverus (sünd 1929), saksa etnoloog ja kultuuriantropoloog, Frankfurdi Goethe-Ülikooli kultuuriantropoloogia ja Euroopa etnoloogia õppetooli rajaja. Tema teos Der territoriale Mensch. Ein literaturanthropologischer Versuch zum Heimatphänomen ilmus Maini-äärses Frankfurdis 1972. aastal (toim).

${ }^{3}$ Ernst Klusen (1909-1988), etnomusikoloog ja helilooja, Saksa Etnoloogia Seltsi (Deutsche Gesellschaft für Volkskunde) laulu-, muusika- ja tantsukomisjoni kauaaegne esimees, asutas 1964. aastal Reinimaa Pedagoogikakõrgkooli Neussi osakonna juurde Etnomusikoloogia õppetooli (mis praeguseks on kolinud Düsseldorfi kaudu Kölni Ülikooli juurde). Hakkas rakendama rahvalaulu-uuringutes sotsiaalteaduste metoodikat, vaatles laulu koos esitusega - seega laulmise fenomeni, tema peateos Singen - Materialien zu einer Theorie ilmus pärast autori surma (toim).

${ }^{4}$ Galit Hasan-Rokem, Soomes sündinud Iisraeli folklorist Jeruusalemma Heebrea ülikooli juudi ja võrdleva rahvaluule professor, ISFNRi neljas, Tartu kongressi aegne president (toim).

\section{Summary}

\section{Reimund Kvideland believed that folklore would never die}

At the onset of last spring, during the $14^{\text {th }}$ World Congress of the International Society for Folk Narrative Research (ISFNR) on July 27, 2005 in Tartu, Norwegian folklorist Reimund Kvideland (1935-2006) said: I'm very optimistic when it comes to the future of folklore itself. If the folkloristics, the study of folklore has a future, is more doubtful. It's difficult to say why, but if we look back historically, in the 19th-century folklore studies, folklore was a national force, it was a political force. [---] Today, at least in Norway, politicians are not interested in folklore studies any longer. So I think, there I'm not that optimistic. Interview with Reimund Kvideland by Ave Tupits. 